Sergii T. Polishchuk, Candidate of Engineering, assoc. Prof. Nikolay N. Bogunenko, assoc. Prof.

\title{
THE ESTIMATION OF HUMAN-OPERATOR CYBERNETIC ABILITIES DURING THE IMPACT OF DESTABILIZING FACTORS OF EXTERNAL ENVIRONMENT
}

The method of estimation of human-operator cybernetics abilities during of the impacting of destabilizing factors of external environment is suggested. It was proved that up-to-date biomedical approach for periodical health examination of pilots in civil aviation isn't guarantees theirs cybernetics abilities in cases of influence of destabilizing factors.

Запропоновано методику очінювання кібернетичної здатності людини-оператора під час діі дестабілізувальних чинників зовнішнього середовища. Доведено, щя сучасний медико-біологічний підхід до контролювання стану здоров'я пілотів циивільної авіації не гарантує їх кібернетичні можливості в умовах діі дестабілізувальних факторів.

criteria of time limit, cybernetics characteristics, destabilizing factor, ergatic system, markers for estimation of human-operator state, probability of goal achievement

\section{Introduction}

The last decades of XX century were characterized by intensive embodiment of informatics in various technological processes, including aviation industry. The automation of processes of air traffic control allowed essentially increases of reliability and safety of air transportation. But, in spite of significant achievements, today in many cases (according to different sources approximately $75 \%$ ), it is possible to affirm, that a human remains one from the main factor of contingencies appearance in the loop of technological process that leads to accidents and catastrophes. Nowadays also it is possible to conjecture that throughout of the long term a humanoperator (HO) can't take out from the control loop of automated system. Therefore, researchers related to increasing of $\mathrm{HO}$ reliability, as inseparable component of the automated control system are topical problem.

\section{Observation of investigations and scientific papers}

In general case the problem of interaction between $\mathrm{HO}$ and technical systems can be considered into three aspects: techno-ergonomic; biomedical; ergatical, i.e. integrated interaction of technical and human components.

Theories of automated control, ergonomics, cybernetics, and informatics are the fundamentals for modern conceptions of techno-ergonomic aspect for the problem decision. The creation of up-to-date air technical realizations such as Ruslan, Mriya, Boeing, and Airbus are the result of long-term researches in indicated areas. Imperfection of techno-ergonomic approach is that the only average values of anthropometrical characteristics, physiology parameters and cybernetics possibilities of the $\mathrm{HO}$ are taken into account during the designing of automated control system. But HO cybernetic abilities (i.e. speed of information perception, speed of information handling and speed of operation reactions) can be variable in space and time, because the physical, medical, psychological, economical, and social factors may influence [1].

Maintenance of $\mathrm{HO}$ basic physiological and biochemical parameters in prescribed limit are the most substantial tasks of biomedical aspect. In aviation for this purpose the periodical tests of pilot health are used [2]. But, these tests don't take into account the correlation between the pilot cybernetic abilities and condition of health in real time of air flight.

The ergatical approach unites with the techno-ergonomical and biomedical conceptions and in additional with the theory of biotechnical systems, engineering physiology, engineering psychology. This allows optimize the parameters of complex system and increase its common efficiency [3]. One from the task of ergatical approach is the quantity representation of bases vital and cybernetics functions of $\mathrm{HO}$. Quantitative representation of the main physiological $\mathrm{HO}$ parameters in on-line mode became especially impotent during of the first orbital manned space activities at the and of 50-th in 20 century. The vagueness of behavior oh cosmonaut organism in the weightless and open cosmic space forces medical and technical sciences to combine their efforts for creation of remote sensing systems. Remote sensing systems in on-line transmit the information about arterial pressure, pulse, respiration rate of cosmonaut to the group of biomedical tracing [4]. I.e., the science came to understanding that on the $\mathrm{HO}$ cybernetic function influence the destabilizing factors of external environment (DFEE). 
And this influence it is necessary take into account in online mode for forecasting of $\mathrm{HO}$ state and exclusion of alarm conditions appearance. And as in previous cases, the imperfection of this approach is that the monitoring data about the HO state haven't connection with his cybernetic possibilities of during the achievement of partial values of general control objective function.

\section{Purpose of research}

The purpose of research is the identification of criteria for determination of $\mathrm{HO}$ physiological state and estimation of DFEE impact on HO cybernetic abilities.

\section{Choice markers for estimation of a human-operator state $\alpha_{1}$}

For taking into account of possible changes in $\mathrm{HO}$ organism which can result in the decline of his cybernetic possibilities will offer the ergatic system (ES) with the loop of estimation of $\mathrm{HO}$ state parameters in real time [5]. Formally this system can be represented as:

$\bar{y}=f(\bar{x}, \bar{z}, \Theta, t)$,

where

$\bar{y}, \bar{x}, \bar{z}$ are vectors of output, input, and disturbance correspondently;

$\Theta$ is vector state of $\mathrm{HO}$ physiological parameters; $t$ is time.

Vector $\Theta$ of $\mathrm{HO}$ state parameters is determined as: $\Theta \in\left\{\alpha_{0} \cup \alpha_{1} \cup \alpha_{2} \cup \alpha_{3} \cup \alpha_{4}\right\}$,

where

$\alpha_{0}$ is cybernetical level;

$\alpha_{1}$ is level of general functioning of physiological organs and systems;

$\alpha_{2}$ is level of psychical adequacy;

$\alpha_{3}$ is level of metabolic status;

$\alpha_{4}$ is level of immune resistance [6].

In the paper [7] is showed that level $\alpha_{0}$ is key in determination of $\mathrm{HO}$ cybernetic possibilities. The probability of limit time of goal achievement by $\mathrm{HO}$ is criteria for estimation of $\alpha_{0}$ level, and can be defined as:

$F_{\text {er }}=p\left\{t \leq t_{\mathrm{L}}\right\}=\int_{0}^{t_{\mathrm{L}}} f(t) d t$,

where $F_{\text {er }}$ is cumulative distribution function of limit time exceeding $t_{\mathrm{L}}$;

$f(t)$ is probability density function of problem time by $\mathrm{HO}$.

The amounts of vector levels $\Theta$, which may be included into analysis, depend on the class problem solved in ES. If for the pilot of civil aviation using level $\alpha_{0}$ and $\alpha_{1}$ are sufficiently, because time of flights usually doesn't exceed 4-6 hours, while for manned space activities it is necessary including all levels of vectors $\Theta$.
Markers of level $\alpha_{1}$ must provide:

- measuring of $\mathrm{HO}$ physiological state without intervention in internal environment of organism;

- without of influence at HO working function;

- enough-sensitiveness for DFEE changes;

- techno-economic realizability.

From the above-mentioned requirements, for our case it is possible to select the next markers of level $\alpha_{1}$ : arterial pressure (AP) of cardiovascular system and heart pulse (HP). For more deep research the respiration rate, blood saturation by oxygen, body temperature and skin conductivity can also be included.

In the joint aviation requirement "Jar-FCL3 Flight Crew Licensing (Medical)" (Jak) selected markers are regulate in following way.

The systolic pressure (SP) mustn't be greater than $160 \mathrm{~mm} \mathrm{Hg}$, diastolic pressure $-95 \mathrm{~mm} \mathrm{Hg}$, $\mathrm{HP}$ - quantity isn't limited.

\section{Monitoring of a human-operator state parameters of $\alpha_{1}$ level}

The method of long-term monitoring is used for the quantitative estimation of possible changes in $\mathrm{HO}$ organism. Monitoring of SP, DP, HP was been passed with the help of automatic measuring device BAT 41-2 during $10 \mathrm{~h}$ with the time interval $10 \mathrm{~min}$. The measuring instrument has such characteristics:

- pressure measuring, 20-280 $\mathrm{mm} \mathrm{Hg}$;

- HP measuring, 30-180 pulse beating;

- absolute error of pressure measuring, $\pm 3 \mathrm{~mm} \mathrm{Hg}$;

- absolute error of HP measuring, $\pm 5 \%$;

- measuring results, which are saved in memory, 600 ;

- maximum time of monitoring, $72 \mathrm{~h}$;

- range of external temperature environment, $10-35{ }^{\circ} \mathrm{C}$;

- overall size of electronics bloc, $92 \times 51 \times 24 \mathrm{~mm}$.

During of monitoring time the pilot of airplane was job, which is characteristically for him every day professional activity. Graphical representation of results measuring and their statistical handling are shown in fig. 1 and tab. 1.

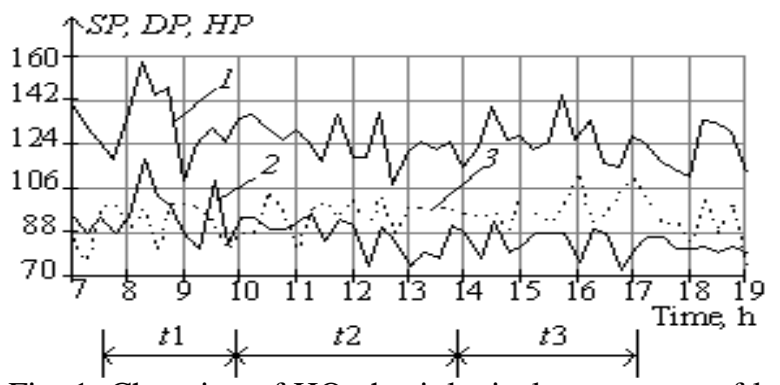

Fig. 1. Changing of HO physiological parameters of level $\alpha_{1}$ during $10 \mathrm{~h}$ :

$1-\mathrm{SP}, \mathrm{mm} \mathrm{Hg}$;

$2-\mathrm{DP}, \mathrm{mm} \mathrm{Hg}$;

3 - HP, beat $/ \mathrm{min}$;

$\mathrm{t}_{1}$ - control of aircraft, $\mathrm{h}$;

$\mathrm{t}_{2}$ - relaxation, $\mathrm{h}$;

$t_{3}$ - control of aircraft, $h$ 
Table 1

SP, DP, HP of HO average-statistical values distributions

\begin{tabular}{|l|c|c|c|}
\hline \multicolumn{1}{|c|}{$\begin{array}{c}\text { Value of } \\
\text { parameters }\end{array}$} & $\begin{array}{c}\mathrm{SP}, \\
\mathrm{mm} \mathrm{Hg}\end{array}$ & $\begin{array}{c}\mathrm{DP}, \\
\mathrm{mm} \mathrm{Hg}\end{array}$ & $\begin{array}{c}\mathrm{HP} \\
\text { beat/min }\end{array}$ \\
\hline Minimum & 107 & 72 & 72 \\
Maximum & 158 & 118 & 112 \\
$\begin{array}{l}\text { Mean } \\
\begin{array}{l}\text { Mean-square } \\
\text { deviation }\end{array}\end{array}$ & 127 & 87 & 94 \\
\hline
\end{tabular}

As can see from tabl.1, the mean value of SP, DP, $\mathrm{HP}$ are equal 127, 87, 94 correspondently. According to this result, it is possible to affirm, that the selected markers of pilot physiological system satisfies of JAR requirements.

But as follows from fig. 1 the considerable deviation of AP and HP from mean value appeared in interval $t 1$. It deviation can be explained by influence of DFEE on the state of pilot's physiological system. In the moment of take-off from departure point the difficult meteorological condition was formed. Such as the low cloudiness, low visibility, low atmospheric pressure, high wind, enhanced solar activity.

And in this case the questing "Could the jump chancing of $\alpha_{1}$ parameters diminish the cybernetics possibilities of $\mathrm{HO}$ characteristics, i.e. the parameters of level $\alpha_{0}$ ?" is appeared.

\section{Experimental research of the influence of the destabilizing factors of external environment at the cybernetics characteristics of a human-operator}

With the goal to answer at the question about parameters $\alpha_{0}, \alpha_{1}$ levels correlation, the next experiment was carried out. The statistical parameters of time distribution of $\mathrm{HO}$ test performing for estimation of his arithmetic capabilities in normal condition of external environment were calculated.

Then, the HO was placed in the heat camber with $40^{\circ} \mathrm{C}$ temperature.

In heat chamber the $\mathrm{HO}$ performs the analogous arithmetic test and simultaneously the SP, DP and HP were being monitored.

The result of measuring of $\alpha_{0}, \alpha_{1}$ parameters are shown in fig. 2 and fig. 3.



Time, $\min$

Fig. 2. Changing of $\mathrm{HO}$ physiological parameters of level $\alpha_{1}$ during the impact of $40^{\circ} \mathrm{C}$ temperature:

$1-\mathrm{SP}, \mathrm{mm} \mathrm{Hg}$;

$2-\mathrm{DP}, \mathrm{mm} \mathrm{Hg}$;

$3-\mathrm{HP}$, beat $/ \mathrm{min}$
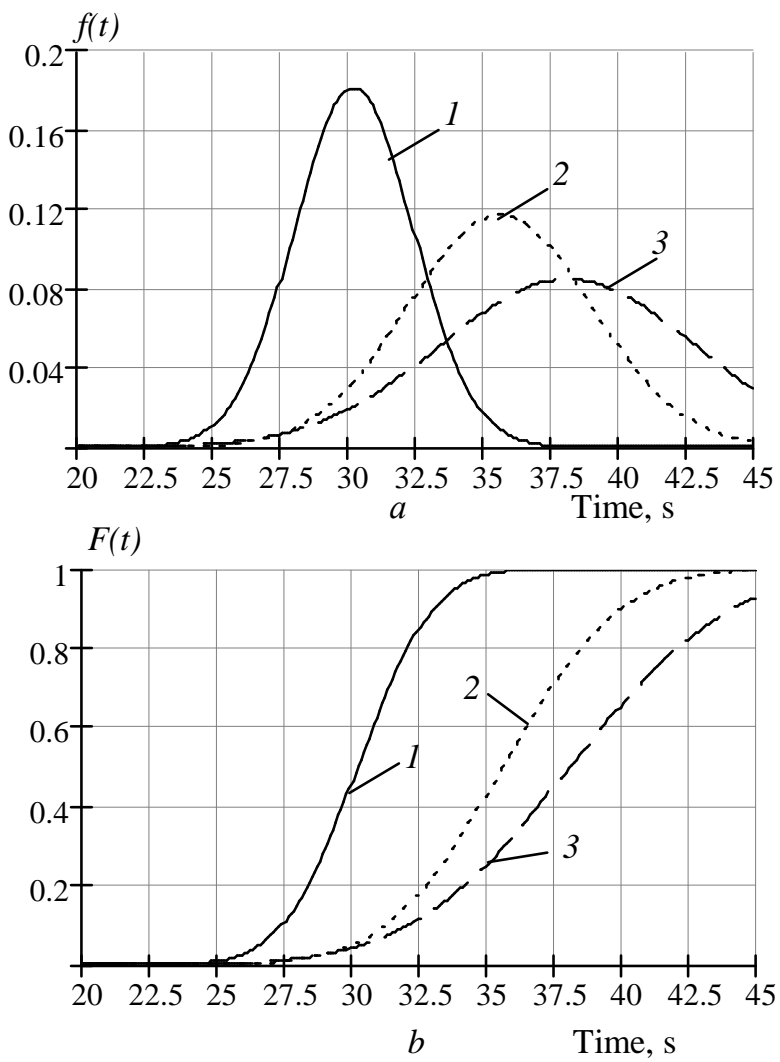

Fig.3. Changing of HO cybernetics ability during the impact of $40^{\circ} \mathrm{C}$ temperature:

$a$ - probability density function of time distribution $f(t)$;

$b$ - cumulative distribution function of time $F(t)$;

1 - normal condition of DFEE;

2 - in $25 \mathrm{~min}$;

3 - in $45 \mathrm{~min}$ 
The statistical handling of data $\alpha_{0}$ level and calculation probability of test execution [equation] in three intervals of time is given in tab. 2 .

Table 2

Changing of probability of test execution

\begin{tabular}{|c|c|c|c|}
\hline Parameters & $\begin{array}{l}\text { Normal } \\
\text { conditi } \\
\text { on of } \\
\text { DFEE }\end{array}$ & $\begin{array}{c}\text { After } \\
25 \text { min of } \\
\text { impact } \\
40^{\circ} \mathrm{C}\end{array}$ & $\begin{array}{c}\text { After } \\
45 \text { min of } \\
\text { impact } \\
40^{\circ} \mathrm{C}\end{array}$ \\
\hline $\begin{array}{l}\text { DP, mm Hg } \\
\text { SP, mm Hg } \\
\text { HP, beat/min } \\
\text { Mathematical } \\
\text { expectation of } \\
\text { execution test } \\
\text { time, c } \\
\text { Root-mean-square } \\
\text { deviation of } \\
\text { execution test } \\
\text { time, c } \\
95 \% \text { probability } \\
\text { of not exceeding of } \\
40 \text { s time limit of } \\
\text { test execution }\end{array}$ & $\begin{array}{c}120 \\
80 \\
65\end{array}$ & $\begin{array}{c}118 \\
62 \\
99\end{array}$ & $\begin{array}{c}127 \\
63 \\
112\end{array}$ \\
\hline
\end{tabular}

\section{Discussion of experimental results}

As can see from tab. 2 the $\mathrm{HO}$ physiological parameters SP, DP, HP, during experiment didn't exceed the limit values, which are regulated by JAR. Bat, the probability of test execution is reduced from 1 to 0.66 . And the velocity of HP was changed in range $65-112$ beats per minute for $40 \mathrm{~min}$.

Then for our case the equation (1) can be rewritten as: $F_{\text {er }}=p\left\{t \leq t_{\mathrm{L}} \mid \begin{array}{l|l}A T \leq A T_{\text {lim }} \\ V H P \leq V H P_{\text {lim }}\end{array}\right\}=\int_{0}^{t_{\mathrm{L}}} f(t) d t$

where VHP is velocity of HP change.

\section{Conclusion}

The modern techno-ergonomic approach to the constriction of ES doesn't enable to predict the influence of $\mathrm{HO}$ on the dynamic characteristics of the system completely, that's caused by absent of information about his cybernetics state in the control loop of automated system.
The method of on-line monitoring of human-operator arterial pressure and pulse rate, and correlation of these parameters with him cybernetics characteristics may be used for information integration in ergatic system.

Periodical human-operator health examination, which nowadays is used in civil aviation isn't enable take into account the impact of destabilizing factors of external environment on cybernetics abilities of human-operator in process of real automated control. The offered approach and above-mentioned experimental data allows assert, that the human-operator arterial pressure and heart rate can be used for prognostication of his cybernetics abilities during achievement of goal in mode of on-line control.

\section{References}

1.Человеческий фактор: в 6 т. Т. 1. Эргономика комплексная научно-техническая дисциплина / пер. с англ. Ж. Кристенсен, Д. Мейстер, П. Фоули и др. М.: Мир, 1991. - 599 с.

2. JAR-FCL Flght Crew Licensing (Medical).- K.: Торгова промислова палата України, 2002. - 101 р.

3. Шибанов Г.П. Количественная оценка деятельности человека в системах человек-техника / Г.П. Шибанов. М.: Машиностроение, 1983. - 263 с.

4. Баевский P. М. Физиологические измерения в космосе и проблема их автоматизации / Р.М. Баевский. - М.: Наука, 1970. - 253 с.

5. Пат. №31879 Украӥна, МКI G05B 13/00. Ергатична система 3 контуром стабілізації параметрів стану біологічної складової / С.Т. Поліщук, В.М. Азарсков, І.Ф. Бойко; опубл. 25.04.08, Бюл. №8. - С. 148.

6. Пат. №33933 Украӥна, МКI А61/М 1/14. Спосіб структурно-інформаційного представлення гомеостазу біологічної системи / С.Т. Поліщук, В.М. Азарсков, А.В. Коломоєць, Д.Д. Іванов; опубл. 25.07.08, Бюл. № 14. - С. 252.

7. Полімук С.T. Методика прогнозування ймовірності виконання завдання людиною-оператором за критерієм ліміту часу / С.Т. Поліщук // Вісник НАУ. 2009. - № 3. - C. 87-90. 